\title{
PHYTOCHEMICAL EVALUATION OF LEAF AND STEM EXTRACTS OF SIDDHA MEDICINAL PLANT: SIDA CORDATA
}

Gulnaz. A. R, Savitha. G

1. Research Scholar. Department of Bio-Chemistry Prist University, Vallam, Thanjavur, Tamil Nadu.

2. Professor. Department of Chemistry, Maharani Science College for Women, Mysore. Karnataka.

\section{CORRESPONDING AUTHOR:}

Gulnaz. A. R,

Assistant Professor, Dept. of Biochemistry,

Farooqia Dental College \& Hospital,

Mysore-21.

E-mail:_gulnazar75@gmail.com

ABSTRACT: Phyto chemicals are the secondary metabolites produce by the plant for its adaptation, which has medicinal value. The plant Sida cordata is a prostrate herb with medicinal value which is found throughout India .The whole plant Sidda cordata is used by the tribal people of Madekeri district to treat various aliment like hepatic disorder, dysentery, cholera etc, it is also one of the component in herbal preparation in Tamilnadu used on cut wounds, to relive pain etc. The traditional medicine involves the use of different plant extracts or bioactive component for the treatment of different health problems at affordable cost. Secondary metabolites are responsible for medicinal activity of plant. Hence, the present study deals with the preliminary phytochemical evaluation of leaf \& stem of Sida cordata, the study includes the preparation of different extracts leaf \&stem by successive solvent extraction method ,fluorescence analysis of successive extracts \& their powder are noted under visible \&UV light, which showed the visibility of varying colors. Further Phytochemical analysis of leaf \& stem extracts of Sida cordata was carried out which confirms the presence of primary metabolites like carbohydrates, amino acids, proteins etc and secondary metabolites like the alkaloids, flavonoids, tannin etc. Present study is designed to explore the preliminary phyto-profile and phytochemical analysis of leaf \& stem of Sida cordata, which are responsible for its pharmacological properties.

KEYWORDS: sidda medicine, Sida cordata, phytochemical screening, successive solvent extraction.

1. INTRODUCTION: Siddha system Medicine is one of the oldest medical systems known to mankind. This system of Siddha medicine is in usage of herbs, metals, and minerals, has originated in Southern India, in the state of Tamil Nadu, as part of the trio Indian medicines, Ayurveda, Siddha, and Unani \& reported to have surfaced more than 2500 years ago. It is assumed that when the normal equilibrium of the three humors (vata, pitha, and kapha) is disturbed, disease is caused. The factors, which assumed to affect this equilibrium, are environment, climatic conditions, diet, physical activities, and stress. Under normal conditions, the ratio between these three humors (vata, pitha and kapha)i.e.:(Vadham, Pittham, Kabam in Tamil) is 4:2:1, respectively. It has both preventive and curative treatments. Preventive include kayakalpa medicines. These Kayakalpa drugs counter the degenerative changes, which leads to aging by means of the Natural antioxidant activity of the herbs. Practicing Siddha medicine is an art rather than a profession. SIDDHA SYSTEM TEACHES us "TO LIVE WITH NATURE". 
Sida cordata (Burm.f.) ${ }^{[1]}$ Waalkes, belongs to the family Malvaceae,is distributed in India, Pakistan and other tropical countries. It is used for the medicinal purposes in the codified Indian systems of medicine namely Ayurveda and Siddha. The whole plant material is believed to rejuvenate and it is also given for chronic liver diseases [2,3,4]. And the roots of these plants along with cow' butter is applied locally to cure piles and relif from the pain .[5] But it has not been explored properly and remains a silent drug in herbal medicine. It is stated in traditional Siddha literature under the author Bhava Mishra, 'Bhava Prakash Nigandu' [6,7,8]. Medicinal herbs have been used in one form or under indigenous form of medicine. Plants have an almost limitless ability to synthesize aromatic substances mainly secondary metabolites, of which at least 12,000 have been isolated, which is less than $10 \%$ of the total. In many cases, these substances serve as the molecules of plant defense against predation by microorganisms, insects, and herbivores. Further, some of which may involve in plant odor (terpenoids), pigmentation (tannins and quinines) etc., It is now clear that, the medicinal values of these plants lie in the bioactive phytochemical constituents that produce definite physiological effects on the human body. Though the traditional Indian system of medicine has a long history of use, they lack adequate scientific documentation, particularly in light modern scientific knowledge[9]. These natural compounds formed are the base of modern drugs which we are using today. [10,11,12] Phytochemicals may protect human beings from various diseases, these are nonnutritive plant chemicals that have protective or disease preventive properties. Phytochemicals are basically divided into two groups that are primary and secondary metabolites according to their functions in plant metabolism. Primary metabolites includes common sugars, amino acids, proteins and chlorophyll while secondary metabolites consist of alkaloids, flavonoids, tannins and so on[13,14]

The present study is carried out on, various leaf \& stem extracts of the plant Sida cordata to explore its phyto constituents which are responsible for its pharmacological properties.

\section{MATERIALS AND METHODS}

\subsection{Plant Collection.}

Fresh plant material, leaves \& stem of Sida cordata was collected from its natural habitat, from the forest region of Somawarpet in Madekeri district Karnataka. The taxonomic identification of this plant was done by the taxonomist from the Dept. of Botany Mysore university Mysore. The collected fresh plant materials (leaves \& stem) were washed in water, shade dried at room temperature and then homogenized to fine powder of 40 mesh size and stored in airtight bottles at $4^{\circ} \mathrm{C}$.

\subsection{Extraction of Plant Material.}

About $100 \mathrm{gm}$ of each leaf \& stem powder were subjected to extraction by a hot percolation method with $150 \mathrm{ml}$ of solvents in their increasing polarity (petroleum ether, chloroform, ethyl acetate, ethanol water respectively), in soxhlet apparatus. Each solvent extraction step was carried out for $24 \mathrm{hrs}$. After extraction, the extracts were concentrated by evaporation and stored at $4^{\circ} \mathrm{C}$ for further study.

Powder \& extracts of leaf and stem were used to determine the physicochemical parameters like extractive values, florescence characteristics, preliminary phyto-profiling and phytochemical analysis, 
2.3. Phytochemical screening: The primary metabolites like proteins, carbohydrates and fixed oils ,fats, etc and the secondary metabolites like, alkaloids, flavonoids, saponins, phenolics, tannins volatile oils, terpenoids, glycosides etc were assessed in the leaf and stem extracts of Sida cordata. as per the standard procedures. [15,16,17].

All the data generated from the study were subjected to arithmetic mean with standard deviation for statistical

RESULTS: The leaf \& stem powder and their extracts were subjected to physiochemical \& phyto chemical analysis and the results obtained were found to be very promising .All the results obtained from the present study are represented in the respective tables $(1,2,3, \& 4)$.

The percentage of yields and the consistency of various extracts were tabulated in table 1.

The consistency was found to be sticky in the non-polar to less polar solvent extracts, whereas the polar solvent extracts were found to be non-sticky. Highest $\%$ of yield $(w / w)$ was recorded in aqueous extract of both leaf \&stem (2gms \& 1.8 gms respectively). The fluorescence characteristics of leaf \& stem powder followed by leaf \& stem extracts was studied under ordinary and UV light $(366 \mathrm{~nm})$.Which showed the visibility of varying colors which are tabulated in the Table no.2 and 3.The preliminary phytochemical screening revealed the presence of most of these compound which are tabulated in table. 4

Primary metabolites like, Protein, Carbohydrate, Fixed oils, fats and secondary metabolites like, alkaloids, flavonoids, saponins, volatile oils, phenols and tannins, glycosides, terpenoids etc were tested .Our investigation result showed that the plant possesses the primary metabolites like, Carbohydrates in all extract of leaf \& stem, however Proteins were found in the aqueous extract only, free amino acids were detected in all the leaf \& stem extracts but, sulphur containing amino acids were absent. Tannins were found in all the leaf \& stem extracts except in the stem extract of ethyl acetate \& ethanol. Flavonoids were detected in all the leaf extracts \& in stem it is present in petroleum ether and ethanol extracts only. Saponins were found only in the ethanol \& aqueous extract of both leaf \& stem. Steroids were found in all the leaf extracts \& in stem it was found only in the aqueous extract. Phenols were found in the ethyl acetate \& aqueous extract of both stem \& leaf. Alkaloids were found in all the leaf extract and completely absent in stem extracts. Anthrocyanins were found only in the ethanol \& aqueous extracts of leaf, it is absent in the all the stem extracts. Coumarins were present in the ethyl acetate extract of leaf only. Emodin were found only in the ethanol extracts of leaf and it is absent in the all the stem extracts. Anthraquinones were found only in the ethanol \& aqueous extracts of leaf, and it is absent in the all the stem extracts. Catechins were found in all the leaf extracts $\&$ in stem it was found only in the aqueous extract.

DISCUSSION: The preliminary phytochemical analysis results revealed the presence of Carbohydrates in all extracts, this may be because these are the essential biomolecules synthesized by the plants abundantly for its energy requirement and other physiological processes. Proteins are present in very negligible amount in the aqueous extracts, this may be due to ,their activity might have been suppressed by the presence of other secondary metabolites, and in addition, probably the solvent might have denatured the proteins because free amino acid were found in all most all the extracts and proteins in the aqueous extract only. Fats \& Volatile oils were completely absent.

The presence of, tannins ${ }^{[18]}$ as a phyto-chemical in Sida cordata leaf \& stem extract reveals that it is useful in the treatment of inflammatory conditions like ulcers and they have 
remarkable activity in cancer prevention. ${ }^{[19]}$ The Flavonoids $\left.{ }^{[20}\right]$ present in extracts are of great importance ,as these are involved in cell protection via their action on membrane permeability, and by inhibiting membrane-bound enzymes such as the ATPase and phospholipase $A_{2}$ [21] .These observations support the usefulness of this plant in folklore remedies in the treatment of stress related ailments and as a dressings for wounds normally encountered in circumcision rites, bruises, cuts and sores [22] . Saponins present in the extracts suggests that this plant may become one of the possible source in the treatment of cancer, because Saponins, are anti carcinogenic agents as they possess surface-active characteristics due their amphiphilic nature of their chemical structure, the proposed mechanisms of anticarcinogenic properties of saponins include direct cytotoxicity, immune-modulatory effects, bile acid binding and normalization of carcinogen-induced cell proliferation. However, the anticarcinogenic effects of saponins from commonly consumed plant foods have not been studied. Soybeans are one of the most important sources of dietary saponins. They are the main protein supplier in many vegetarian diets.[23]

The leaf \& stem extract also contains steroids which are very important compounds especially in the synthesis of sex hormone.[24].The presence of phenolic compounds in this plant contributed to their anti-oxidant properties and thus its usefulness in herbal medicament. Alkaloids present in the extracts have been associated with medicinal uses for centuries and one of their common biological properties is their cytotoxicity [25]. Anthrocyanins present in the extract helps the immune system to work more efficiently to protect against viral infection It is little bit more complex, specific types of Anthrocyanins may have a direct effect in decreasing influenza viruses infectivity by decreasing the ability of the virus itself to get into the human cell or to be related [26]. The presence of coumarin in the extracts may serve as a potent natural anti oxidant because various studies have been demonstrated that coumarin is a potential antioxidant and its antioxidant activity is due to its ability to scavenge free radicals and to chelate metal ions [27]. Presence of Emodin in the extracts shows that this plant can be used as anticancerous, antimicrobial and anti-inflammatory agent because many pharmaceutical studies have demonstrated that emodin has many biological effects, such as anticancer, antimicrobial and anti- inflammatory effects [28]. Prencese of Anthraquinones in the extracts are of great importance as Anthraquinones are considered to be one of the most active agents in metastatic breast cancer. [29]

Presences of Catechins in the extracts are also has greater importance because Catechins transcriptomic studies shows that catechin reduces atherosclerotic lesion development in apo E- deficient mice [30]. And catechin seem to have stereospecific opposite effects on glycogen metabolism in isolated rathepatocytes [31]. Catechin inhibits intestinal tumor formation in mice.[32] Catechin inhibits the oxidation of low density lipoprotein.[33]. The presence of Emodin, Anthraquinones, and Catechin in the leaf \& stem extracts of Sida cordata may be used as a potent drug in the treatment of cancer.

Although, absence of certain phytochemicals in one extract and its presence in the other can be safely attributed to the various physiological and biosynthetic reactions taking place inside the plant, the effect of the environment should not be neglected, as the environment always modify the things. Anti microbial \& preliminary phytochemical analysis of various extracts from different plants have been of great interest in both research \& also in food industries because of their possible use as natural additives emerges from the growing tendency to replace synthetic antioxidants. 
By considering the above facts we can conclude that the leaf \& stem of the plant Sida cordata are of great medicinal value, which is routinely used by many tribal people in the Madikeri district for the treatment of various diseases, leaf \& stem containing these compounds may also serve as potent medicament for the treatment of inflammatory disorders and in cancer.

Further studies are in progress on Sida cordata as anti microbial, anti oxidant, anti inflammatory, anti-carcinogenic source and, other biochemical properties, isolation of the bioactive compounds responsible for the therapeutic value for the benefit of human welfare.

Table 1: Preliminary phyto-profile for leaves \& stem of Sida cordata

\begin{tabular}{|l|l|l|l|l|l|l|l|}
\hline S. no. & \multirow{2}{*}{ Solvent used } & \multicolumn{2}{|l|}{ color } & \multicolumn{2}{l|}{ consistency } & \multicolumn{2}{l|}{ of yield w/w } \\
\cline { 3 - 8 } & & Leaves & stem & Leaves & stem & Leaves & Stem \\
\hline 01 & Petroleum ether & Green & Light Green & Sticky & Sticky & 1.3 & 0.9 \\
\hline 02 & Chloroform & Green & Green & Sticky & Sticky & 1.9 & 1.3 \\
\hline 03 & Ethyl acetate & Dark Green & Green & Sticky & Sticky & 1.4 & 1.1 \\
\hline 04 & Ethanol & Green & Green & Non Sticky & Non Sticky & 1.8 & 1.2 \\
\hline 05 & Water & Brownish & Brownish & Non Sticky & Non Sticky & 2.0 & 1.8 \\
\hline
\end{tabular}

Table 2: Florescence characteristic of leaf \& stem powder of Sida cordata

\begin{tabular}{|c|c|c|c|c|c|}
\hline \multirow[t]{2}{*}{$\begin{array}{l}\text { S. } \\
\text { no. }\end{array}$} & \multirow[t]{2}{*}{$\begin{array}{l}\text { Particulars of the } \\
\text { treatment }\end{array}$} & \multicolumn{2}{|c|}{ Under ordinary light } & \multicolumn{2}{|c|}{$\begin{array}{l}\text { Under UV light (366 } \\
\text { nm) }\end{array}$} \\
\hline & & Leaves & stem & Leaves & stem \\
\hline 01 & Powder as such & Green & Green & Dark green & Black \\
\hline 02 & $\begin{array}{l}\text { Powder }+1 \mathrm{~N} \quad \mathrm{NaOH} \\
\text { (aqueous) }\end{array}$ & $\begin{array}{l}\text { Greenish } \\
\text { brown }\end{array}$ & Grown & Black & Black \\
\hline 03 & $\begin{array}{l}\text { Powder }+1 \mathrm{~N} \\
\text { (alcoholic) }\end{array}$ & Light green & Light green & orange & Black \\
\hline 04 & Powder + 1N HCl & colorless & colorless & yellowish & Yellow \\
\hline 05 & Powder $+\mathrm{H}_{2} \mathrm{SO}_{4}(1: 1)$ & Pale yellow & Pale yellow & orange & orange \\
\hline 06 & Powder $+\mathrm{HNO}_{3}(1: 1)$ & Reddish & Reddish & Black & orange \\
\hline 07 & Powder + Ammonia & $\begin{array}{l}\text { Florescent } \\
\text { green }\end{array}$ & $\begin{array}{l}\text { Florescent } \\
\text { green }\end{array}$ & orange & orange \\
\hline 08 & Powder + Iodine & brown & brown & Black & Black \\
\hline 09 & Powder $+5 \% \mathrm{FeCl}_{3}$ & Blackish green & Pale yellow & Black & Black \\
\hline 10 & Powder + Acetic acid & Grey & Greenish & Black & Black \\
\hline
\end{tabular}


Table 3: Florescence characteristic of leaves \&stem extract of Sida cordata

\begin{tabular}{|l|l|l|l|l|l|}
\hline Sl. No. & \multirow{2}{*}{ Extract } & \multicolumn{2}{|l|}{ Under ordinary light } & \multicolumn{2}{l|}{ Under UV light (366 nm) } \\
\cline { 3 - 6 } & & Leaves & stem & Leaves & stem \\
\hline 01 & Petroleum ether & Green & Green & Black & Black \\
\hline 02 & Chloroform & Florescent Light Screen & Green & Brown & Black \\
\hline 03 & Ethyl acetate & Dark Green & Green & Black & Black \\
\hline 04 & Ethanol & Green & Green & Black & Black \\
\hline 05 & Water & Brown & Brown & Black & Black \\
\hline
\end{tabular}

Table4: Phytochemical analysis of different extracts of leaves \&stem of Sida cordata

\begin{tabular}{|c|c|c|c|c|c|c|c|c|c|c|c|c|}
\hline \multirow{2}{*}{$\begin{array}{l}\text { S. } \\
\text { No. }\end{array}$} & \multirow{2}{*}{$\begin{array}{l}\text { Phyto } \\
\text { compounds }\end{array}$} & \multirow[t]{2}{*}{ Name of the Test } & \multicolumn{2}{|c|}{ P E* } & \multicolumn{2}{|c|}{$\mathrm{Ccl}_{4^{*}}$} & \multicolumn{2}{|c|}{ Et.a* } & \multicolumn{2}{|c|}{ Et.oh* } & \multicolumn{2}{|c|}{$\mathbf{H}_{2} \mathbf{O}^{*}$} \\
\hline & & & $\mathbf{L}^{*}$ & $\mathbf{S}^{*}$ & $\mathbf{L}^{*}$ & $S^{*}$ & $\mathbf{L}^{*}$ & $S^{*}$ & $\mathbf{L}^{*}$ & $\mathbf{S}^{*}$ & $\mathbf{L}^{*}$ & $\mathbf{S}^{*}$ \\
\hline \multirow[t]{4}{*}{01} & \multirow[t]{4}{*}{ Alkaloids } & a.Mayer's test & + & - & + & - & + & - & + & - & - & - \\
\hline & & b.Wager'test & + & - & + & - & + & - & + & - & - & - \\
\hline & & c.Dragondoff' test & + & - & + & - & + & - & + & - & - & - \\
\hline & & d.Hager's test & + & - & + & - & + & - & + & - & - & - \\
\hline \multirow[t]{2}{*}{02} & \multirow{2}{*}{$\begin{array}{l}\text { Phytosterols } \\
\text { /triterpenoids }\end{array}$} & a. Liebermann Test & + & - & + & - & + & - & + & - & + & + \\
\hline & & b. Salkowski Test & + & - & + & - & + & - & + & - & + & + \\
\hline \multirow[t]{2}{*}{03} & \multirow[t]{2}{*}{ Saponins } & a. Froth test & - & - & - & - & - & - & - & + & + & + \\
\hline & & b. Foam test & - & - & - & - & - & - & - & + & + & + \\
\hline \multirow[t]{2}{*}{04} & \multirow[t]{2}{*}{ carbohydrate } & a.Molisch's test & + & + & + & + & + & + & + & + & + & + \\
\hline & & b. Benedict's test & + & + & + & + & + & + & + & + & + & + \\
\hline 05 & Tannins & Gelatin test & + & + & + & + & + & - & + & - & + & + \\
\hline \multirow[t]{2}{*}{06} & \multirow[t]{2}{*}{ Flavonoids } & a. Alkaline reagent test & + & + & + & - & + & - & - & + & + & - \\
\hline & & b. Lead acetate test & + & + & + & - & + & - & - & + & + & - \\
\hline 07 & Glycosides & Borntrager's test & + & + & + & + & + & + & - & - & + & + \\
\hline 08 & Fixed oil/fat & Spot test & - & - & - & - & - & - & - & - & - & - \\
\hline 09 & Phenol & Ferric chloride test & - & - & - & - & + & + & + & - & + & + \\
\hline 10 & Gum & & - & - & - & - & - & - & - & - & - & - \\
\hline \multirow[t]{3}{*}{11} & \multirow[t]{3}{*}{ Proteins } & a. Biurete test & - & - & - & - & - & - & - & - & + & + \\
\hline & & $\begin{array}{l}\text { b. Lead acetate test for } \\
\text { sulphur containing amino } \\
\text { acids }\end{array}$ & - & - & - & - & - & - & - & - & - & - \\
\hline & & c. Xanthoproteic test & + & + & + & + & + & + & + & + & + & + \\
\hline
\end{tabular}




\begin{tabular}{|l|l|l|l|l|l|l|l|l|l|l|l|l|}
\hline & & d. Ninhydrin test & + & + & + & + & + & + & + & + & + & + \\
\hline 12 & Volatile oil & & - & - & - & - & - & - & - & - & - & - \\
\hline 13 & Coumarin & & - & - & - & - & + & - & - & - & - & - \\
\hline 14 & Emodin & & - & - & - & - & - & - & + & - & - & - \\
\hline 15 & Anthrocyanin & & - & - & - & - & - & - & + & + & + & + \\
\hline 16 & Anthraquinones & Sulphuric acid test & - & - & - & - & - & - & + & + & + & + \\
\hline 17 & Catechins & Erhlish test & + & - & + & - & + & - & + & - & + & + \\
\hline
\end{tabular}

L -leaf, S-stem, PE- petroleum ether, $\mathrm{Ccl}_{4}$, chloroform, Et.a-ethyl acetate, Et.oh-ethanol

\section{REFERENCE:}

1. Paul \& Nayar in Nayar et al. (eds.), Fasc. Fl. India 19:206. 1988; Paul in Sharma \& Sanjappa (eds.), Fl. India 3:283. 1993, all in parts

2. Agasthiar Pannendayiram Ennum Perunool Kaviyam, 2nd Edn. 1995,Thamarai Noolagam, Chennai, pp-322.

3. Bhava Mishra, B P Nigandu, 4th Edn. 1985, pp-585.

4. J Munisamy Anbarashan, N Parthasarthy and A Padmavathy Journal of Medicinal Plants Research Vol. 5(3), pp. 439-443, 4 February, 2011

5. M.P. Panthi and R.P.Chaudhary. Antibacteriactivity of some selected folklore medicinal plants from west Nepal American-Eurasian Journal of Scientific Research 4 (3): 142-147, 2009

6. S Mistry,K R Dutt,Sashi Bhusan Biswal,, J Jena, Protective and curative effect of poly herbal formulation containing indigenous medicinal plants against various hepatotoxic agents in rats 2012 by the Asian Pacific Journal of Tropical Biomedicine

7. C. Chitravadivu, M. Bhoopathi, V. Balakrishnan, T. Elavazhagan and S. Jayakumar Antimicrobial Activity of Laehiums Prepared by Herbal Venders, South India Americaneurasian journal of scientific research 4(3):142-147.2009

8. D. Gnanasekaran, C. Umamaheswara Reddy, B. Jaiprakash, N. Narayanan, S. H. Elizabeth, Adaptogenic activity of a Siddha medicinal plant: Sida cordata Int J Pharm Biomed Res 2012, 3(1), 7-11

9. Akinmo-laudn, Ibukun, EO, Afor, E, Obuotor, EM and Farombi, EO Phytochemical Constituents and Antioxidant Activity of Extracts from leaves of O.Gratissimum, Sci. Res. Essay 2:163-166

10. Adome RA, Gachichi JW, Onegi B, Tamale J and Apio. The cardiotonic effect of The Crude Ethanolic extract of Nerium oleander in the isolated Guinea pig hearts. African Health Sciences 2003; 3 (2): 77-82.

11. Ayoola GA, Coker HAB, Adesegun SA, Adepoju-Bello AA, Obaweya K, Ezennia EC, Atangbayila TO. Phytochemical Screening and Antioxidant Activities of Some Selected Medicinal Plants Used for Malaria Therapy in Southwestern Nigeria. Tropical Journal of Pharmaceutical Research 2008; 7 (3): 1019-1024

12. C.K. Hindumathy In Vitro Study of Antibacterial Activity of Cymbopogon Citratus World Academy of Science, Engineering and Technology 74 2011, 193-197.

13. Deb AC, Fundamentals of Biochemistry, New Central Book Agency, Kolkatta. VIII the Edition. 6. 
14. Edeoga HA, Okwu DE, and Mbaebie BO . Phytochemical constituent of some Nigerian Medicinal Plants, African journal of Biotechnology academic journals 2005; 4: 685-688

15. Harborne , J.B (1998).Phytochemical Methods, Chapman and Hall Publications,London, 7-8.

16. Obasi NL, Egbuonu ACC, Ukoha PO, Ejikeme PM.Comparative phytochemical and antimicrobial screening of some solvent extracts of Samaneasaman pods. African journal of pure and applied chemistry 2010; 4(9): 206-212.

17. Audu SA, Mohammed I, Kaita HA. Phytochemical screening of the leaves of Lophira lanceolata (Ochanaceae). Life Science Journal 2007; 4(4): 75-79.

18. Li H, Wang Z, Liu Y: Review in the studies on tannins activity of cancer prevention and anticancer.Zhong-Yao-Cai 2003, 26(6):444-448.

19. Hausteen B: Flavonoids, a class of natural products of high pharmacological potency. Biochem Pharm 1983, 32:1141-1148.

20. Ruch RJ, Cheng SJ, Klaunig JE: Prevention of cytotoxicity and inhibition of Intercellular communication by antioxidant catechins isolated from Chinese green tea. Carcinogens 1989, 10:1003- 1008.

21. Motar MLR, Thomas G, Barbosa Fillo JM: Effects of Anacardium occidentale stem bark extract on in vivo inflammatory models. J Ethnopharm Zhong-Yao-Cai 2003, 26(6):444448.

22. Grierson DS, Afolayan AJ: Antibacterial activity of some indigenous plants used for the treatment of wounds in the Eastern Cape. S Afr J Ethnopha.

23. Rao AV, Sung MK. Saponins as anticarcinogens. J Nutr (1995) 125:717S-24S.

24. Okwu DE: Evaluation of the chemical composition of medicinal plants belonging to Euphorbiaceae. Pak Vet J 2001, 14:160-162.

25. Nobori T, Miurak K, Wu DJ, Takabayashik LA, Carson DA: Deletion of the cyclindependent kinase-4 inhibitor gene in multiple human cancers. Nature 994, 368 (6473): 753-756.

26. Liu, A.L., et al., 2009. In vitro anti-influenza viral activities of constituents from Caesalpinia sappan Planta Med., 75: 337-9

27. Tseng, A., 1991. Chemoprevention of tumors in.

28. MTV-H ras transgenic mice with coumarins.Proc. Am. Assoc. Cancer. Res., 32: 2257

29. Wang, C.H., Z.Q. Gao, B. Ye, J.T. Cai, C.G. Xie, K.D. Qian and Q. Du, 2007. Effect of emodin on pancreatic fibrosis in rats, World J. Gastroenterol., Res. 13: 378-382.

30. K. Asha, C. T. Rasika, R. D. Nirmala, P. S. Jyoti, Ann. Biol. Res., 2011, 2, 1, 176-18

31. S Auclair, D Milenkovic, C Besson, S Chauvet, E Gueux, C Morand, A Mazur and A Scalbert, Catechin reduces atherosclerotic lesion development in apo E-deficient mice: A transcriptomic study Atherosclerosis, Volume 204, Issue 2, June2009,21e27 doi:10.1016/j.atherosclerosis.2008.12.007

32. Nyfeler, Fritz; Moser, Ulrich K.; Walter, Paul (1983). "Stereospecific effects of (+)- and $(-)$-catechin on glycogen metabolism in isolated rat hepatocytes". Biochimica et Biophysica Acta (BBA) - Molecular Cell Research 763: 50.doi:10.1016/01674889(83)90024-1.

33. Michael J. Weyant, Adelaide M. Carothers, Andrew J. Dannenberg and Monica M. Bertagnolli, Catechin Inhibits Intestinal Tumor Formation and Suppresses Focal Adhesion Kinase Activation in the Min/+ Mouse. Cancer Research 61, 118-125, January 1, 2001 